\title{
PENGARUH LABA (RUGI) BERSIH DAN ARUS KAS BERSIH TERHADAP RETURN \\ SAHAM PADA PERUSAHAAN MANUFAKTUR AUTOMOTIVE AND ALLIED \\ PRODUCTS YANG TERDAFTAR DI BURSA EFEK INDONESIA
}

\author{
Abdonsius Sitanggang,SE,Msi,Akt
}

\section{ABSTRACT}

\begin{abstract}
Abdonsius Sitanggang,SE,Msi,Akt, In manufacturing companies Automotive and Allied Products listed on the Indonesia Stock Exchange in 2006-2007 showed fluctuations of income (loss), net cash flows and stock returns and the consequences of the rise and fall of income (loss) and cash flows cause stock returns fluctuate too. So the problem is formulated "the influence of income (loss) and net cash flow to stock return at manufacturing Automotive and Allied Products listed on the Indonesia Stock Exchange."
\end{abstract}

This study aimed to investigate the effect of income (loss) and net cash flow to stock return on the company manufacturing Automotive and Allied Products listed on the Indonesia Stock Exchange. Benefits of the research is as one of the considerations for potential investors in making investment decisions. The population in this study are all manufacturing Automotive and Allied Products listed on the Indonesia Stock Exchange observation period 2006-2007. The sample in this study is a population of around 19 companies with saturated sampling method. Hypothesis testing is performed using multiple linear regression models.

The results of F-test (ANOVA test) showed that the net income (loss) (X1) and net cash flow (X2) jointly have a positive and significant impact on the company's stock returns Automotive and Allied Products listed on the Indonesia Stock Exchange, with significance level of $0.014<0.05$. Determinant coefficient () of 0.215 or $21.5 \%$, explained that the dependent variable is the stock return can be explained independent variable is net income (loss) and net cash flow by $21.5 \%$, while $78.5 \%$ is explained by other factors.

Coefficient of income (loss) (X1), t-hit $<t$-tabs, and significant at the $0.994>0.05$, indicating that the net income (loss) in partial positive and significant effect on stock returns Automotive and manufacturing companies Allied Products listed on the Indonesia Stock Exchange. Net cash flow coefficient (X2), $t$-hit $<t-t a b$ and significant at $0.008<0.05$, indicating that the net cash flows is partially positive and significant impact on stock returns in manufacturing Automotive and Allied Products listed on the Stock Securities Indonesia.

Keywords: Income (loss) (Net Profit and Loss), Net cash flow (Net Cash Flow), Stock Return (Return on Stock)

\section{Latar Belakang}

Kinerja perusahaan yang baik menurut pandangan investor adalah jika perusahaan mampu memberikan tingkat pengembalian (return) yang tinggi atas investasinya serta mampu membayar bunga serta mengembalikan pinjamannya atau kewajibannya tepat waktu. Teori akuntansi tentang hubungan informasi laba bersih dan arus kas bersih mempunyai pengaruh terhadap return saham. Dengan demikian perlu dibuktikan dengan penelitian empiris, apakah informasi laba bersih dan arus kas tersebut pada perusahaan manufaktur yang terdaftar di Bursa Efek Indonesia mempunyai pengaruh yang signifikan terhadap return saham. 
Pasar modal merupakan alternatif investasi dan pendanaan bagi masyarakat bisnis. Dalam mekanisme pasar modal, perusahaan melalui emiten dapat memperoleh dana untuk menjalankan bisnisnya dengan cara menjual sahamnya. Perusahaan-perusahaan yang bergerak dibidang manufacture maupun non manufacture terutama yang listing di bursa efek harus mempublikasikan laporan keuangannya. Laporan keuangan sebagai informasi utama sangat penting bagi pihak-pihak yang berkepentingan dalam mengambil keputusan investasi. Laporan keuangan yang merupakan informasi kinerja dan pertanggungjawaban manajemen terdiri dari neraca, laporan rugi laba, laporan ekuitas dan laporan arus kas. Pernyataan Standar Akuntansi Keuangan No 2 paragraf 01. PSAK No. 2 paragraf 01 menyatakan bahwa perusahaan harus menyusun laporan arus kas dan menyajikan laporan tersebut sebagai bagian yang tidak terpisahkan dari laporan keuangan untuk setiap periode penyajian laporan keuangan.

Informasi laba (rugi) bersih dan arus kas bersih sebagai salah satu dasar pengambilan keputusan investasi, investor maupun calon investor perlu mengetahui dan memahami pengaruh informasi laba (rugi) bersih dan arus kas tersebut, sehingga keputusan investasi lebih akurat. Informasi laba (rugi), laporan arus kas bersama dengan analisis item laporan keuangan lainnya akan membantu perusahaan, investor, kreditur, dan pemerintah untuk mengetahui kemampuan perusahaan untuk menghasilkan laba, arus kas masuk dan arus kas keluar pada masa yang akan datang serta kemampuan membayar dividen atau return saham dan kekuatan internal perusahaan.

Return saham sangat dipengaruhi oleh kondisi keuangan perusahaan. Tingkat keuntungan (return) merupakan motivasi investor dalam berinvestasi; maka return seringkali dijadikan sebagai ukuran untuk membandingkan berbagai alternatif investasi. Pengukuran return memungkinkan investor mengetahui keberhasilan mereka dalam melakukan suatu investasi serta peranan mereka dalam memperkirakan return masa depan. Tujuan investor dalam berinvestasi pada umumnya adalah untuk memperoleh deviden dan untuk memperoleh capital gain. Perilaku investor seperti ini mengindikasikan bahwa mereka membeli saham pada saat harga saham turun dan menjualnya kembali pada saat harga saham naik. Indikasi ini menyimpulkan bahwa seorang calon investor yang ingin membeli saham di pasar sekunder harus senantiasa memperhatikan pergerakan harga saham untuk memprediksi return saham tersebut. Pergerakan harga saham ini dipengaruhi oleh kinerja perusahaan yang dapat diamati melalui analisis profitabilitas dan arus kas.

Penelitian Wilson (1986) pada perusahaan manufacture di Bursa Efek Jakarta menyatakan bahwa arus kas berpengaruh positip yang signifikan terhadap return saham. Eric (1997), telah melakukan pengujian hubungan laba dan arus kas terhadap return saham pada perusahaan manufacture di Bursa Efek Jakarta, menyatakan bahwa ada hubungan yang kuat antara laba dan arus kas dari aktivitas operasi dengan return saham. Ali (1994), dalam penelitian pada perusahaan perbankan di Bursa Efek Jakarta menunjukkan hasil bahwa laba, modal kerja, dan cash flow berpengaruh signifikan terhadap return saham.

Penelitian ini merupakan replikasi dari ketiga peneliti sebelumnya. Perbedaan penelitian ini dengan penelitian sebelumnya adalah bahwa objek penelitian ini adalah pada perusahaan manufaktur Automotive and Allied Products yang terdaftar di Bursa Efek Indonesia pada tahun 2006-2007. 
Tabel Data Laba (rugi) bersih, Arus kas bersih, dan Return Saham perusahaan manufaktur Automotive and Allied Products yang terdaftar di Bursa Efek Indonesia tahun $2006-2007$.

\begin{tabular}{|c|c|c|c|c|}
\hline KODE SAHAM & TAHUN & LABA BERSIH (dalam rupiah) & ARUS KAS (dalam rupiah) & RETURN SAMAM \\
\hline \multirow[t]{2}{*}{ 1. $A D M G$} & 2006 & $\quad(266.963 .936 .000)$ & $(140.170 .335 .000)$ & -0.375 \\
\hline & 2007 & 57.976 .636 .000 & 54.180 .061 .000 & -0.125 \\
\hline \multirow[t]{2}{*}{ 2. ASII } & 2006 & 3.712097 .000 .000 & 4.650 .450 .000 .000 & 0.5676 \\
\hline & 2007 & 6.519 .273 .000 .000 & 1.396 .943 .000 .000 & 0.7388 \\
\hline \multirow{2}{*}{ 3. AUTO } & 2006 & 282.058 .000 .000 & 22.814 .000 .000 & 0.0660 \\
\hline & 2007 & 454.907 .000 .000 & 133.582 .000 .000 & -0.1367 \\
\hline \multirow[t]{2}{*}{ 4. BRAM } & 2006 & 18.313 .909 .000 & 53.091 .286 .000 & 1.0340 \\
\hline & 2007 & 39.148 .712 .000 & 93.374 .000 .000 & 0.0331 \\
\hline \multirow[t]{2}{*}{ 5. GIBO } & 2006 & 118.401 .000 .000 & $(40.218 .000 .000)$ & -0.0680 \\
\hline & 2007 & 90.841 .000 .000 & 330.341 .000 .000 & 0.9830 \\
\hline \multirow{2}{*}{ 6. GDYR } & 2006 & 25.396 .749 .000 & 10.699 .766 .000 & 0.0357 \\
\hline & 2007 & 42.399 .174 .000 & $(12.171 .150 .000)$ & -0.1446 \\
\hline \multirow[t]{2}{*}{ 7. HEXA } & 2006 & 39.428 .484 .000 & 34.622 .267 .000 & 0.0448 \\
\hline & 2007 & 56.623 .000 .000 & 23.202 .000 .000 & 0.1544 \\
\hline \multirow[t]{2}{*}{ 8. IMAS } & 2006 & 1.248 .000 .000 & $(80.857 .284 .000)$ & -0.3204 \\
\hline & 2007 & 1.382 .852 .000 & 38.616 .000 .000 & 0.6714 \\
\hline \multirow[t]{2}{*}{ 9. INDS } & 2006 & 2.171 .591 .000 & 4.297 .756 .000 & 0.0400 \\
\hline & 2007 & 9.887 .928 .000 & 5.630 .092 .000 & 2.0208 \\
\hline \multirow[t]{2}{*}{ 10. INTA } & 2006 & 7.065 .909 .000 & 4.600 .457 .700 & 0.1724 \\
\hline & 2007 & 9.513 .888 .000 & 5.780 .013 .500 & 0.1458 \\
\hline \multirow[t]{2}{*}{ 11. LPIN } & 2006 & $(939.128 .000)$ & 6.084 .086 .000 & 0.2000 \\
\hline & 2007 & 18.034 .504 .000 & 55.280 .868 .000 & 1.0667 \\
\hline \multirow[t]{2}{*}{ 12. MASA } & 2006 & 170.007 .000 .000 & $(3.447 .540 .000)$ & -0.35 \\
\hline & 2007 & 29.204 .000 .000 & 16.680 .709 .000 & 0.016 \\
\hline \multirow[t]{2}{*}{ 13. NIPS } & 2006 & 7.650 .174 .000 & 9.506 .103 .500 & 0.0461 \\
\hline & 2007 & 6.393 .947 .300 & 12.023 .682 .500 & 0.3603 \\
\hline \multirow[t]{2}{*}{ 14. PRAS } & 2006 & 2.761 .454 .000 & 5.372 .071 .600 & 0.3333 \\
\hline & 2007 & 2.773 .565 .000 & $(888.568 .500)$ & 0.4778 \\
\hline \multirow[t]{2}{*}{ 15. SMSM } & 2006 & 66.174 .829 .000 & $(28.927 .130 .500)$ & -0.1475 \\
\hline & 2007 & 80.324 .965 .000 & 1.598 .134 .300 & 0.2285 \\
\hline \multirow[t]{2}{*}{ 16. SQM! } & 2006 & $(7.903 .000 .000)$ & $(78.000 .000)$ & 0.0833 \\
\hline & 2007 & 607.000 .000 & 34.768 .000 .000 & 1.9230 \\
\hline \multirow[t]{2}{*}{ 17. SUGI } & 2006 & 343.783 .000 & 1.544 .617 .000 & 0.5200 \\
\hline & 2007 & 3.689 .899 .000 & $(1.138 .634 .700)$ & 0.2667 \\
\hline \multirow[t]{2}{*}{ 18. TURI } & 2006 & 22.211 .000 .000 & $(108.430 .000 .000)$ & -0.0362 \\
\hline & 2007 & 189.816 .000 .000 & 9.636 .000 .000 & 0.8239 \\
\hline \multirow[t]{2}{*}{ 19. UNTX } & 2006 & 930.372 .000 .000 & 379.020 .000 .000 & 0.8054 \\
\hline & 2007 & 1.493 .037 .000 .000 & 187.280 .000 .000 & 0.6870 \\
\hline
\end{tabular}

Sumber: www.jsx.co.id dan Indonesian Capital Market Directory 2008

Dari tabel di atas, ditunjukkan bahwa pada tahun 2006 terdapat 6 perusahaan yang memiliki return negatif dan 13 perusahaan yang memiliki return positif. Sedangkan pada tahun 2007 terdapat 3 perusahaan yang memiliki return negatif dan 16 perusahaan yang memiliki return positif. Dari tabel di atas dapat disimpulkan bahwa return saham perusahaan ada yang positif dan ada yang negatif.

\section{Perumusan Masalah}

Penelitian Wilson (1986) pada perusahaan manufacture di Bursa Efek Jakarta menyatakan bahwa Arus kas berpengaruh positip signifikan terhadap return saham. Hasil penelitian Eric 
(1997), pada perusahaan manufacture di Bursa Efek Jakarta, menyatakan bahwa ada hubungan yang kuat antara laba dengan return saham, serta arus kas dari aktivitas operasi dengan return saham. Ali (1994), hasil penelitiannya pada perusahaan perbankan di Bursa Efek Jakarta menunjukkan hasil bahwa laba, modal kerja, dan cash flow berpengaruh signifikan terhadap return saham.

Pada tahun 2006 terdapat 6 perusahaan pada perusahaan manufaktur Automotive and Allied Products yang terdaftar di Bursa Efek Indonesia memiliki return saham negatif dan 13 perusahaan yang memiliki return saham positif. Pada tahun 2007 terdapat 3 perusahaan pada perusahaan Automotive and Allied Products yang terdaftar di Bursa Efek Indonesia memiliki return saham negatif dan 16 perusahaan yang memiliki return saham positif. Dengan demikian bahwa Return saham berfluktuasi positif dan negatif. Penelitian ini akan menguji kembali pengaruh laba (rugi) bersih dan arus kas bersih terhadap return saham pada perusahaan manufaktur Automotive and Allied Products yang terdaftar di Bursa Efek Indonesia. Dengan demikian masalah dirumuskan sebagai berikut :"Bagaimana pengaruh laba (rugi) bersih dan arus kas bersih terhadap return saham pada perusahaan manufaktur Automotive and Allied Products yang terdaftar di Bursa Efek Indonesia"

\section{Pengebangan Teori dan Hipatesis}

Menurut Tandelilin ( $2001: 13$ ), Peran utama dari pasar modal adalah sebagai sarana penghubung antara perusahaan emiten dengan para investor dan calon investor. Investasi dalam bentuk saham memberikan dua keuntungan (return saham) bagi investor yakni : dividen dan capital gain. Dividen adalah bagian keuntungan yang diberikan perusahaan kepada para pemegang saham pada periode tertentu. Dividen merupakan salah satu daya tarik bagi pemegang saham. Capital Gain adalah selisih lebih antara harga beli dengan harga jual. Capital Gain terbentuk dari aktivitas perdagangan saham yang terjadi di pasar sekunder. Investor dengan orientasi jangka pendek biasanya cenderung mengejar keuntungan melalui capital gain.

Laporan keuangan adalah suatu media informasi yang mengungkap semua aktivitas perusahaan dan sebagai pertanggungjawaban manajemen kepada pemegang saham, pemilik perusahaan dan kepada pihak ekstern lainnya. Laba (rugi) bersih dan arus kas bersih merupakan indikator kinerja keuangan perusahaan. Fungsi laporan keuangan ini telah berkembang sebagai alat pengawasan dan alat pertanggungjawaban mengenai suber dan penggunaan dana dan lebih utama sebagai alat ukur kinerja perusahaan yang sangat berperan sebagai alat dan pedoman pengambilan keputusan investasi. Investor membutuhkan informasi laporan keuangan tersebut untuk menilai apakah perusahaan memiliki kemampuan untuk membayar dividen dan untuk menilai apakah investasinya akan tetap dipertahankan atau dijual.

Wild dan Halsey (2005 : 25) menyatakan bahwa laba (earnings) atau laba bersih (net income) mengindikasikan profitabilitas perusahaan. Laba (rugi) merupakan kenaikan atau penurunan ekuitas sebelum distribusi kepada pemegang saham dan kontribusi dari pemegang saham atau ekuitas. Laba merupakan kenaikan aktiva besrsih yang dapat menarik minat calon investor dan kreditor. Laba (rugi) bersih akan mempengaruhi jumlah dividen sebagai pengembalian atas investasi saham yang disebut return saham.

Laporan arus kas mengklasifikasikan penerimaan kas (cash received) dan pengeluaran kas (cash disbursement) berdasarkan tiga jenis aktivitas yaitu aktivitas operasi, aktivitas investasi dan aktivitas pendanaan. Klasifikasi menurut aktivitas ini akan memberikan 
informasi yang memungkinkan para pengguna laporan keuangan untuk menilai pengaruh aktivitas tersebut pada posisi keuangan perusahaan serta terhadap jumlah kas dan setara kas, baik arus kas masuk (in - flows) maupun arus kas keluar (out - flows). Kegagalan perusahaan untuk menghasilkan arus kas yang besar untuk suatu periode yang panjang dapat merupakan tanda adanya kesulitan keuangan. Jumlah arus kas yang berasal dari aktivitas operasi merupakan indikator yang menentukan apakah dari operasi perusahaan dapat menghasilkan arus kas yang cukup untuk melunasi pinjaman, memelihara kemampuan operasi perusahaan, membayar dividen, dan melakukan investasi baru tanpa mengandalkan sumber pendanaan dari luar.

Menurut Horngren, Harrison, (1998: 845), menyatakan bahwa ontuk memperkirakan arus kas masa mendatang, sumber dan penggunaan kas tidaklah berubah secara drastis dari tahun ke tahun sehingga penerimaan dan pengeluaran kas dapat diterima sebagai alat yang baik untuk memperkirakan penerimaan dan pengeluaran kas dimasa mendatang. Untuk mengevaluasi pengambilan keputusan manajemen, manajer selalu berusaha mengambil keputusan yang terbaik yang diharapkan dapat membantu perusahaan mempertahankan kelangsungan hidupnya serta kemampuan bersaing. Sebagian besar faktor keberhasilan perusahaan ditentukan oleh keputusan manajer khususnya top level management yang biasanya diharapkan dengan pengambilan kegiatan investasi perusahaan-perusahaan sehingga memberikan informasi kepada investor dan kreditor untuk mengevaluasi keputusan manajer.

Modal suatu perusahaan biasanya terdiri dari saham serta modal pinjaman. Pemegang saham tertarik untuk menanamkan modal atau sahamnya di perusahaan karena harapan akan memperoleh dividen dari aktivitas pendanaan tersebut. Kreditur akan memperoleh penghasilan dari perusahaan karena akan memperoleh bunga dari pokok pinjamannya tepat waktu. Laporan arus kas membantu investor dan kreditur untuk mengetahui apakah perusahaan bisa melakukan pembayaran-pembayaran tersebut.

Laba bersih dan arus kas selalu bergerak bersama. Tingkat laba menyebabkan perubahan pada peningkatan dan penurunan arus kas. Nilai kas bisa menurun ketika laba bersih rendah dan naik ketika laba bersi tinggi. Adanya kemungkinan bangkrutnya suatu perusahaan yang mempunyai laba bersih yang cukup tetapi kas yang rendah, menyebabkan diperlukannya informasi arus kas. Menurut SAK (2002: 2.1), jika digunakan dalam kaitannya dengan laporan keuangan lain, laporan arus kas dapat memberikan informasi yang memungkinkan para pemakai untuk mengevaluasi perubahan dalam aktiva bersih, stuktur keuangan (termasuk likuiditas dan solvabilitas) dan kemampuan untuk mempengaruhi jumlah serta waktu arus kas dalam rangka adaptasi dengan perubahan keadaan dan peluang. Laporan kenaikan atau penurunan bersih dalam kas dipandang berguna karena investor, kreditor dan pihak-pihak lainnya yang berkepentingan ingin mengetahui dan memahami apa yang terjadi dalam sumber daya perusahaan yang paling lancar yaitu kasnya.

Tingkat pengembalian dan keuntungan atau return saham adalah pendapatan atau imbalan hasil yang akan diperoleh para investor dari investasi saham. Menurut Jogiyanto (2003:109), "Return merupakan hasil yang diperoleh dari investasi". Return dapat berupa return realisasi dan return ekspetasi. Return realisasi merupakan return yang sudah terjadi dan dihitung berdasarkan data historis. Return realisasi penting karena digunakan sebagai salah satu pengukur kinerja dari perusahaan dan penentuan return ekspetasi dan risiko dimasa 
datang. Return ekspetasi adalah return yang diharapkan akan diperoleh investor dimasa mendatang. 2003:111) :

Rumus untuk menghitung return saham dinyatakan sebagai berikut (Jogiyanto,

$$
R t=\frac{P_{t}-P_{t-1}+D_{t}}{P_{t-1}}
$$

Dimana :

Rt $\quad=$ Return saham pada waktu ke $-t$

Pt = Harga saham pada waktu $-t$

Pt-1 = Harga saham pada waktu $t-1$

Dt $\quad=$ Dividen tunai yang dibayarkan secara periodik

Analisis pendekatan terhadap saham dapat dibagi dua, yaitu pendekatan fundamental dan pendekatan teknis. Pendekatan fundamental menyatakan bahwa setiap saham memiliki nilai intrinsik. Untuk menentukan nilai tersebut, dipakai pertimbangan berdasarkan unsur keuangan yang fundamental seperti pendapatan dan dividen. Dalam pendekatan fundamental dikenal tiga metode yang lazim digunakan, yaitu:

1. Net Tangible Assets Approach

Metode ini menerangkan bahwa nilai intrinsik saham adalah perbandingan antar equity dengan jumlah saham yang beredar atau dapat dirumuskan sebagai berikut.

Harga saham $=\frac{\text { totalequity }}{\text { jumlahsahamyangberedar }}$

Asumsi yang mendasari pendekatan ini adalah dukungan nilai aktiva sebagai cadangan untuk setiap lembar saham yang beredar. Diasumsikan tidak mungkin perusahaan tergantung pada harga jual atau likuidasi aktiva tanpa dipertimbangkan aktiva berwujud.

2. Earning Approach

Pendekatan ini dirumuskan sebagai berikut:

Harga saham $=$ Price Earning Rasio $\times$ Earning Per Share

Angka ini didapat dari perbandingan pendapatan bersih dengan jumlah saham yang beredar. Price Earning Rasio (PER) menggambarkan besarnya perbandingan antara harga pasar saham per lembar dengan laba per lembar saham yang dirumuskan sebagai berikut:

PER $=\frac{\text { hargasanam }}{\text { EFs }}$

Kenaikan rasio ini menüjukkan bahwa saham perusahaan yang bersangkutan semakin tidak menarik dalam hubungannya dengan keputusan investasi. Investor menggunkan PER untuk menghubungkan laba tahun berjalan terhadap harga yang berlaku saat ini.

3. Deviden Yield Approach

Pendekatan ini menjelaskan sebagai distribusi pendapatan bagi pemilik perusahaan, baik dalam bentuk dividen tunai maupun dividen saham.

Dividen Yield $=\frac{\text { dividen psr sañm }}{\text { nomgotentom }}$

Salah satu keputusan dividen yang dihubungkan dengan dividen yang dibagikan yield approach ini adalah dengan membandingkan persentase dividen yang dibagikan tersebut dengan investasi lainnya seperti deposito bank. 
Pendekatan Teknis menyatakan bahwa investasi adalah sebagai makhluk rasional yaitu rasional yang tidak melihat fundamental perusahaan apabila membeli saham perusahaan tersebut. Pendekatan ini lebih mendekati pada pendekatan psikologi. Pendekatan teknis menyatakan faktor utama yang menyebabkan gerakan harga saham naik atau turun dimasa yang akan datang termasuk laba dan deviden yang akan diberikan sehingga dapat terjadi kecenderungan perubahan terhadap harga pasar saham.

Penelitian ini akan membuktikan secara empiris tentang pengaruh informasi laba (rugi) bersih dan arus kas bersih terhadap return saham. Informasi akuntansi diprediksi mempengaruhi perilaku investor untuk berinvestasi untuk memperoleh return saham. Informasi Arus kas bersih pada prinsipnya lebih penting daripada laba akuntansi, karena laba belum tentu mengindikasikan kas dalam periode tersebut. Menurut Brigham dan Houstoun (2001:46) "arus kas bersih (net cash flow) lebih penting, karena investor lebih cenderung melihat arus kas perusahaan daripada laba bersih walaupun informasi laba (rugi) bersih juga penting karena dividen harus dibayar secara tunai dan karena kas diperlukan dalam membeli aktiva untuk melanjutkan operasi perusahaan" sedangkan laba bisa saja masih dalam bentuk piutang atau persediaan. Maka informasi laba (rugi) bersih dan arus kas bersih berpengaruh terhadap perilaku investor untuk berinvestasi yang apabila dalam bentuk saham, mengakibatkan harga saham akan meningkat atau menurun dan akan berpengaruh terhadap return saham.

Profiabilitas merupakan ukuran kemampuan menghasilkan laba, dengan demikian laba maupun rugi bersih adalah informasi yang mengindikasikan profitabilitas, atau merupakan indikator daripada profitabilitas. Jika profitabilitas meningkat, maka secara umum akan menarik minat investor membeli saham perusahaan, dan akan meningkatkan harga saham serta akan meningkatkan return saham. Tetapi kenaikan profitabilitas belum tentu akan menaikkan jumlah kas bersih dan belum tentu meningkatkan kemampuan perusahaan untuk membayar dividen, padahal investor lebih mengharapkan kemampuan perusahaan membayar dividen. Dengan demikian informasi laba (rugi) bersih kurang berpengaruh terhadap harga saham dan return saham.

Kenaikan maupun penurunan kas bersih sangat berhubungan dengan kenaikan dan penurunan laba (rugi) bersih. Jika arus kas bersih meningkat, belum tentu disebabkan oleh profitabilitas yang meningkat; tetapi investor akan cenderung tertarik untuk membeli saham perusahaan tersebut jika profitabilitas meningkat dan arus kas bersih meningkat. sehingga harga saham akan naik, dan akan mengakibatkan return saham meningkat juga. Maka hipotesis penelitian dirumuskan sebagai berikut:

H1 : Laba (rugi) bersih berpengaruh positif signifikan terhadap return saham pada perusahaan manufaktur Automotive and Allied Products yang terdaftar di Bursa Efek Indonesia.

$\mathrm{H} 2$ : Arus kas bersih berpengaruh positif signifikan terhadap return saham pada perusahaan manufaktur Automotive and Allied Products yang terdaftar di Bursa Efek Indonesia.

\section{METODE PENELITIAN}

\section{Populasi dan sampel}

Populasi dalam penelitian ini adalah seluruh perusahaan manufaktur Automotive and Allied Products yang terdaftar di Bursa Efek Indonesia periode tahun 2006-2007 yaitu sebanyak 19 perusahaan. Sampel yang digunakan ditentukan dengan teknik sampling jenuh. Menurut 
Sugiyono (2009:124) "sampling jenuh adalah teknik penentuan sampel bila semua anggota populasi digunakan sebagai sampel.

\section{Operasionalisasi Variabel}

Variabel dalam penelitian ini adalah Laba (rugi) bersih, Arus kas bersih dan Return saham. Variabel independen $(X)$ dalam penelitian ini adalah:

1. Laba (rugi) bersih (X1). Laba (Rugi) bersih $=$ Penjualan - (Cost of Good Sold+Biaya Operasi+Penyusutan + Bunga+Pajak).

2. Arus kas bersih (X2). Arus kas bersih yaitu jumlah kas bersih yang tersedia baik dari aktivitas operasi, investasi, dan pendanaan.

Variabel dependen $(Y)$ dalam penelitian ini adalah Return Saham. Return saham adalah pengembalian atas suatu investasi. Return saham merupakan perbandingan antara harga saham sekarang dengan periode sebelumnya ditambah dengan deviden tunai.

Rumus untuk menghitung return saham dinyatakan sebagai berikut (Jogiyanto, 2003 :111).

$$
\begin{aligned}
& R t=\frac{P_{t}-P_{t-1}+D_{t}}{P_{t-1}} \\
& \text { Dimana Rt : Return saham pada waktu ke }-\mathrm{t} \\
& \text { Pt : Harga saham pada waktu -t } \\
& \text { Pt-1 : Harga saham pada waktu } t-1 \\
& \text { Dt : Dividen tunai yang dibayarkan secara periodik. }
\end{aligned}
$$

\section{Teknik Pengumpulan Data}

Data yang digunakan adalah laporan keuangan tahunan dan harga saham perusahaanperusahaan Automotive and Allied Products yang terdaftar di Bursa Efek Indonesia pada 20062007 yang bersumber dari Indonesian Capital Market Directory (ICMD 2008) untuk data laba (rugi) bersih dan harga saham, serta www.jsx.co.id untuk data arus kas.

\section{TEKNIK PENGUMPULAN DATA}

\section{Uji Asumsi Klasik}

Menurut Ghozali (2005), untuk menghasilkan suatu model yang baik, analisis regresi memerlukan pengujian asumsi klasik sebelum melakukan pengujian hipotesis. Pengujian asumsi klasik tersebut meliputi uji normalitas, uji multikolinieritas, uji heteroskedastisitas, dan uji autokorelasi.

Uji normalitas bertujuan untuk menguji apakah dalam model regresi, variabel penganggu atau residual memiliki distribusi normal". Ada dua cara yang dapat digunakan untuk mendeteksi apakah variabel pengganggu atau residual memiliki distribusi normal atau tidak yaitu dengan analisis grafik dan uji statistik. Analisis Grafik pada prinsipnya normalitas dapat dideteksi dengan melihat penyebaran data (titik) pada sumbu diagonal dari grafik atau dengan mélihat histogram dari residualnya. Analisis Statistik yang dapat digunakan untuk menguji normalitas residual adalah uji statistik Kolmogorov-Smirnov (K-S).

Uji multikolinieritas bertujuan untuk menguji apakah model regresi ditemukan adanya korelasi antar variabel bebas (independen). Model regresi yang baik seharusnya tidak terjadi korelasi di antara variabel independen. Multikolinieritas dapat dideteksi dengan melihat nilai Tolerance dan Variance Inflation Factor (VIF). Nilai cut off yang umum dipakai untuk 
menunjukkan adanya multikolinieritas adalah nilai tolerance $<0,10$ atau sama dengan VIF $>$ 10. Di samping itu, suatu model dikatakan memiliki gejala multikolinieritas apabila koefisien korelasi diantara variabel bebas lebih besar dari 0,9 .

Uji heteroskedastisitas bertujuan untuk menguji apakah dalam model regresi terjadi ketidaksamaan variance dari residual satu pengamatan ke pengamatan yang lain". Model regresi yang baik adalah tidak terjadi heteroskedastisitas. Deteksi ada tidaknya heteroskedastisitas dapat dilakukan dengan melihat ada tidaknya pola tertentu pada grafik scatterplot antara SRESID dan ZPRED dimana sumbu $Y$ adalah $Y$ yang telah diprediksi dan sumbu $X$ adalah residual ( $Y$ prediksi - $Y$ sesungguhnya) yang telah di-studentized.

Uji autokorelasi bertujuan untuk menguji apakah dalam model regresi linear ada korelasi antara kesalahan pengganggu pada periode $t$ dengan kesalahan pengganggu pada periode t-1 (sebelumnya). Jika terjadi korelasi maka dinamakan ada problem autokorelasi. Model regresi yang baik adalah regresi yang bebas dari autokorelasi. Salah satu cara yang dapat digunakan untuk mendeteksi ada atau tidaknya autokorelasi adalah dengan melakukan uji Durbin-Waston (DW test), yaitu:

$$
\mathrm{DW}=\frac{\sum_{t=2}^{t=n}\left(\varepsilon_{1}-\varepsilon_{t-1}\right)}{\sum_{t=n}^{t=n} z t^{2}}
$$

Pengambilan keputusan ada tidaknya autokorelasi adalah:

\begin{tabular}{|l|c|c|}
\hline \multicolumn{1}{|c|}{ Hipotesis nol } & Keputusan & Jika \\
\hline Tidak ada autokorelasi positif & Tolak & $0<\mathrm{d}<\mathrm{dl}$ \\
Tidak ada autokorelasi positif & No desicison & $\mathrm{dl} \leq \mathrm{d} \leq \mathrm{du}$ \\
Tidak ada korelasi negatif & Tolak & $4-\mathrm{dl}<\mathrm{d}<4$ \\
Tidak ada korelasi negatif & No desicison \\
Tidak ada autokorelasi positif atau & Tidak ditolak \\
negative & & 4-du $\leq \mathrm{d} \leq 4-\mathrm{dl}$ \\
\hline
\end{tabular}

\section{Pengujian Hipotesis}

Model penelitian ini adalah menggunakan model Regresi Linear Berganda. Model tersebut dinyatakan dalam bentuk rumus atau fungsi sebagai berikut:

$$
Y=\alpha+\beta_{1} X_{1}+\beta_{2} X_{2}+e
$$

$\begin{array}{cl}\text { Dimana } Y & \text { : Return saham } \\ a & : \text { Konstanta } \\ X_{1} & \text { : Net Income } \\ X_{2} & : \text { Arus kas (Cash flow) } \\ \beta_{1}, \beta_{2} & : \text { Koefisien variabel independen } \\ e & : \text { Variabel pengganggu / standar error }\end{array}$

Untuk menguji hipotesis digunakan uji $t$ - ( $t$ - test) menggunakan tingkat signifikansi dengan alfa $=0,05$. Hipotesis statistik dirumuskan sebagai berikut:

Ho: $\beta_{1}=0$ : Artinya laba (rugi) bersih tidak berpengaruh terhadap return saham pada perusahaan manufaktur Automotive and Allied Products yang terdaftar di Bursa Efek Indnesia.

Ha : $\beta_{1} \neq 0$ : Artinya laba (rugi) bersih pengaruh terhadap return saha. pada perusahaan manufaktur Automotive and Allied Products yang terdaftar di Bursa Efek Indnesia. 
Ho: $\beta_{2}=0$ : Artinya Arus kas bersih tidak berpengaruh terhadap return saham pada perusahaan manufaktur Atomotive and Allied Products yang terdaftar di Bursa Efek Indonesia.

Ha: $\beta_{2} \neq 0$ : Artinya Arus kas bersih berpengaruh terhadap return saham pada perusahaan manufaktur Automotive and Allied Products yang terdaftar di Bursa Efek Indnesia.

Pengujian ini dilakukan dan dibuktikan dengan kriteria statistik sebagai berikut:

- Jika thitung $>t_{\text {tabel }}$ pada $\alpha=0.05$, maka H0 diterima

- Jika thitung $<t_{\text {tabel }}$ pada $\alpha=0.05$, maka H0 ditolak.

Untuk menguji dan membuktikan pengaruh secara sumultan, dilakukan dengan uji $\mathrm{F}$ (Anova -test). Uji ini dilakukan untuk melihat pengaruh laba (rugi) bersih dan arus kas bersih secara bersama-sama terhadap return saham pada perusahaan manufaktur Automotive and Allied Products yang terdaftar di Bursa Efek Indonesia. Hipotesis statistiknya dirumuskan sebagai berikut :

Ho: $\beta_{1}, \beta_{2}=0$ : Artinya Laba (rugi) bersih dan Arus kas tidak berpengaruh terhadap return saham pada perusahaan manufaktur Automotive and Allied Products yang terdaftar di Bursa Efek Indnesia.

Ha: $\beta_{1}, \beta_{2} \neq 0$ : Artinya Laba (rugi) bersih dan Arus kas berpengaruh terhadap return saha. pada perusahaan manufaktur Automotive and Allied Products yang terdaftar di Bursa Efek Indnesia.

Hasil pengujian ini dibuktikan dengan kriteria statistik sebagai berikut:

- Jika $F_{\text {hitung }}>F_{\text {tabel }}$ pada $\alpha=0.05$, maka H0 diterima

- Jika $F_{\text {hitung }}<F_{\text {tabel }}$ pada $\alpha=0.05$, maka H0 ditolak.

\section{HASIL PENELITIAN DAN PEMBAHASAN}

\section{Deskripsi Variabel Penelitian}

Objek penelitian ini adalah 19 perusahaan manufaktur Automotive And Allied Products yang terdaftar di Bursa Efek Indonesia periode tahun 2006-2007 dengan sampel data berjumlah 38. Dari data sampel menunjukkan bahwa pada tahun 2006 ada 2 perusahaan yang mengalami rugi dan 17 perusahaan memperoleh laba. Perusahaan yang megalami rugi paling besar adalah PT Polychem Indonesia Tbk yaitu sebesar Rp (266.963.936.000) sedangkan perusahaan yang memperoleh laba terbesar adalah PT Astra Internasional yaitu sebesar Rp 3.712.097.000.000. Arus kas tertinggi adalah PT Astra Internasional Tbk. yaitu sebesar 4.650.450.000.000, dan Arus kas terendah adalah PT Polychem Indonesia Tbk. yaitu sebesar Rp (140.170.335.000). Nilai return saham tertinggi adalah PT Branta Mulia Tbk yaitu 1.0340 atau $103,40 \%$ dan return saham terendah adalah PT Sugi Samapersada Tbk yaitu 0.375 atau $-37.5 \%$. Pada tahun 2007 semua perusahaan memperoleh laba dan laba terbesar adalah PT Astra Internasional Tbk yaitu sebesar Rp 6.519.273.000.000. Arus kas tertinggi adalah PT Astra Internasional sebesar Rp 1.396.943.000.000 dan Arus kas terendah adalah PT Godyear Indonesia Tbk sebesar Rp (12.171.150.000); Nilai return saham tertinggi adalah PT Indospring Tbk yaitu 2,02 atau $202 \%$ dan return saham terendah adalah PT Godyear Indonesia Tbk yaitu -0.14 atau $-14 \%$.

Dari deskripsi data sampel laba (rugi) bersih, arus kas bersih, dan return saham diatas, terdapat range yang sangat jauh. Dengan demikian disimpulkan bahwa tidak selamanya jika laba (rugi) meningkat atau menurun mengakibatkan return saham akan meningkat atau menurun. Demikian juga bahwa tidak selamanya jika laba (rugi) bersih dan arus kas bersih 
positif maka return saham akan positif juga, atau tidak selamanya jika laba (rugi) bersih dan arus kas bersih negatif maka return saham akan negatif juga.

\section{Pengujian Asumsi Klasik \\ Uji Normalitas}

Hasil pengujian menunjukkan bahwa distribusi residual relatif normal, hal ini ditunjukkan dalam grafik. Normal probabilty plot juga menunjukkan hal yang sama dimana titik-titik dalam plot terlihat menyebar mendekati dan searah garis diagonal, hal ini telah sesuai dengan kriteria dan dengan demikian data adalah normal.

\section{Uji Normalitas dengan Histogram}

Histogram

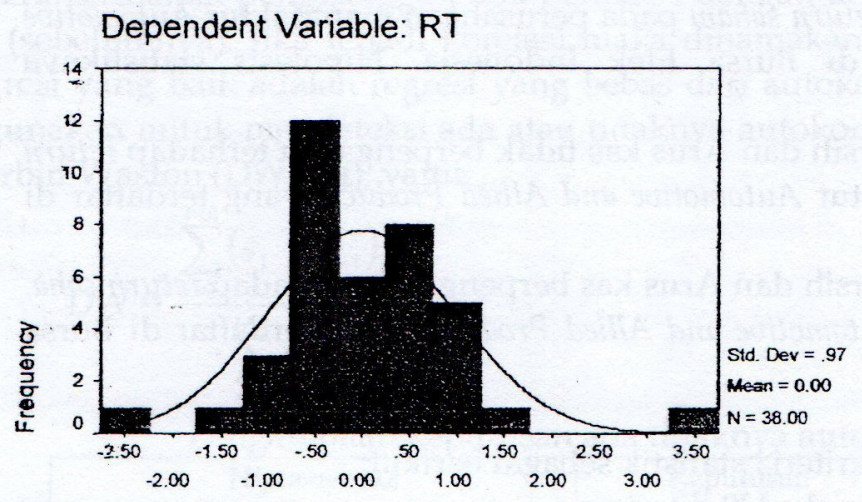

Regression Standardized Residual

Sumber : Hasil SPSS versi 10.

Uji Normalitas dengan Plot

Normal P-P Plot of Regression Standar

Dependent Variable: RT

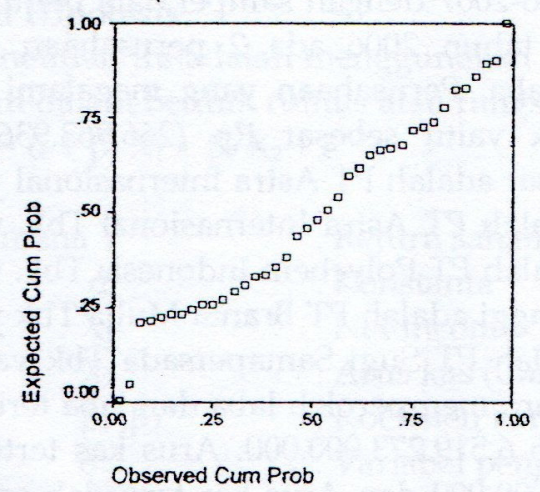

Sumber : Hasil SPSS versi 10

Selain uji grafik dilakukan juga uji statistik yaitu Uji Kolmogorof-Smirnov (K-S), Uji K-S ini mensyaratkan nilai signifikansi dari residual lebih besar dari 0,05 agar suatu distribusi residual dianggap normal. Hasil dari uji ini dapat dilihat pada tabel berikut: 
One-Sample Kolmogorov-Smirnov Test

\begin{tabular}{|c|c|c|c|}
\hline & & & $\begin{array}{l}\text { Unstandardiz } \\
\text { ed Residual }\end{array}$ \\
\hline \multicolumn{3}{|l|}{$N$} & 38 \\
\hline \multirow[t]{2}{*}{ Normal Parameters } & $a, b$ & Mean & $-5.39187 E-10$ \\
\hline & & Std. Deviation & .4853495 \\
\hline Most Extreme & & Absolute & .119 \\
\hline \multirow[t]{2}{*}{ Differences } & & Positive & .119 \\
\hline & & Negative & -.118 \\
\hline \multicolumn{3}{|c|}{ Kolmogorov-Smirnov Z } & .732 \\
\hline \multicolumn{3}{|l|}{ Asymp. Sig. (2-tailed) } & .658 \\
\hline
\end{tabular}

a. Test distribution is Normal.

b. Calculated from data.

Sumber : Hasil SPSS versi 10

Dári tabel diatas dapat dilihat bahwa nilai Kolmogorov-Smirnov sebesar 0,732 dan signifikan pada 0.658 , hal ini berarti data berdistribusi normal dengan kriteria sebagai berikut: $N=38$ berarti sampel yang diamati ada sebanyak 38 sampel data, Nilai Kolmogorov-Smirnov 0,732 dengan probabilitas $0.658>0,05$ pada uji normalitas Kolmogorov-Smirnov. Oleh karena itu nilai $p$ untuk variabel yang diuji $>0,05$ maka diketahui bahwa data variabel pada 38 sampel adalah normal atau memenuhi syarat uji normalitas. Dapat disimpulkan bahwa secara keseluruhan distribusi residual sudah normal.

\section{Uji Multikolinieritas}

Pengujian multikolinieritas dapat dilakukan dengan melihat nilai VIF dan korelasi antar variabel bebas. Jika nilai VIF $>10$ atau nilai tolerance $<0,10$ maka terjadi multikolinieritas. Disamping itu, suatu model dikatakan memmiliki gejala multikolinieritas apabila koefisien korelasi diantara variabel bebas lebih besar dari 0,9 . Hasil pengujian untuk ada tidaknya multikolinieritas adalah sebagai berikut:

\begin{tabular}{|c|c|c|c|c|}
\hline & \multicolumn{3}{|c|}{ Coefficient Correlations } & \multirow[b]{2}{*}{ NI } \\
\hline Model & & & CF & \\
\hline \multirow[t]{4}{*}{1} & Correlations & CF & 1000 & -416 \\
\hline & & NI & -416 & 1000 \\
\hline & Covariances & CF & $1035 F-04$ & $-7.82 F-05$ \\
\hline & & NI & $-782 F-05$ & $3 \triangle 12 \mathrm{~F}-\mathrm{n} \triangle$ \\
\hline
\end{tabular}

a. Denendent Variable: RT

Sumber : Hasil SPSS versi 10

Coefficients $^{2}$

\begin{tabular}{|c|c|c|c|c|c|c|c|c|}
\hline \multirow{2}{*}{\multicolumn{2}{|c|}{ Model }} & \multicolumn{2}{|c|}{$\begin{array}{l}\text { Unstandardized } \\
\text { Coefficients }\end{array}$} & \multirow{2}{*}{$\begin{array}{c}\begin{array}{c}\text { Standardi } \\
\text { zed } \\
\text { Coefficien } \\
\text { ts }\end{array} \\
\text { Beta }\end{array}$} & \multirow[b]{2}{*}{$t$} & \multirow[b]{2}{*}{ Sig. } & \multicolumn{2}{|c|}{ Collinearity Statistics } \\
\hline & & $B$ & Std. Error & & & & Tolerance & VIF \\
\hline & (Constant) & .176 & .177 & & .997 & .326 & & \\
\hline & NI & $1.343 E-04$ & .018 & .001 & .007 & .994 & .827 & 1.210 \\
\hline & $\mathrm{CF}$ & $2.859 \mathrm{E}-02$ & .010 & .463 & 2.811 & .008 & .827 & 1.210 \\
\hline
\end{tabular}

a. Dependent Variable: RT

Sumber : Hasil SPSS versi 10 
Dari tabel di atas dapat dilihat bahwa hasil besaran korelasi antar variabel independen adalah $-0,416$ atau sekitar $41,6 \%$. Oleh karena korelasi ini masih di bawah $95 \%$ maka dapat dikatakan bahwa tidak terjadi multikolinieritas yang serius.

Hasil perhitungan nilai tolerance juga menunjukkan tidak ada variabel independen yang memiliki nilai tolerance kurang dari 0,10 yang berarti tidak ada korelasi antar variabel yang nilainya lebih 95\%. Hasil perhitungan nilai Variance Inflation Factor (VIF) juga menunjukkan hal yang sama, tidak ada variabel independen yang memiliki nilai VIF lebih dari 10. Jadi dapat disimpulkan bahwa tidak ada multikolinieritas antar variabel independen dalam model regresi.

\section{Uji Heteroskedastisitas}

Untuk melihat ada tidaknya heteroskedastisitas dapat diakukan dengan melihat grafik Scatterplot antara nilai prediksi variabel dependen yaitu ZPRED dengan residualnya SRESID. Jika ada pola seperti titik-titk yang membentuk pola tertentu yang teratur maka terjadi heteroskedastisitas. Namun, jika tidak ada pola yang jelas serta serta tidak menyebar ke atas dan di bawah angka 0 pada sumbu $X$ maka terjadi heteroskedastisitas, namun jika ada pola yang jelas serta titik menyebar ke atas dan di bawah angka 0 pada sumbu $Y$ maka tidak terjadi heteroskedastisitas. Dari hasil pengujian diperoleh bahwa tidak ada pola yang teratur; dengan demikian tidak ada heteroskedastisitas. Hasil dari uji heteroskedastisitas dapat ditunjukkan dalam grafik Scatterplot antara ZPRED dan SRESID sebagai berikut:

Scatterplot

Dependent Variable: RT

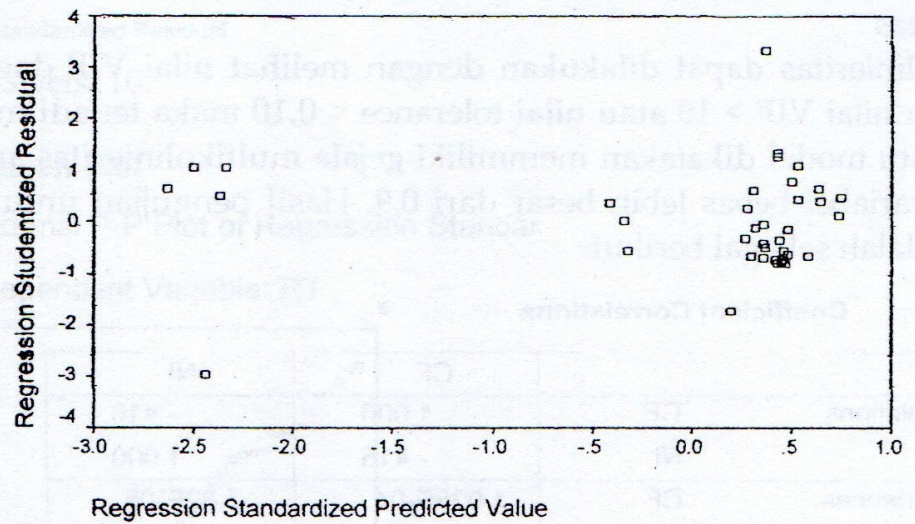

Sumber : Hasil SPSS versl 10

\section{Uji Autokorelasi}

Untuk mendeteksi ada tidaknya autokorelasi digunakan uji Durbin Watson. Hasil Uji Autokorelasi adalah sebagai berikut.

\section{Model Summany}

\begin{tabular}{|l|r|r|r|r|c|}
\hline Model & R & R Square & $\begin{array}{c}\text { Adjusted } \\
\text { R Square }\end{array}$ & $\begin{array}{c}\text { Std. Error of } \\
\text { the Estimate }\end{array}$ & $\begin{array}{c}\text { Durbin-W } \\
\text { atson }\end{array}$ \\
\hline 1 & $.464^{2}$ & .215 & .170 & .4990 & 2.263 \\
\hline
\end{tabular}

a. Predictors: (Constant), CF, NI

b. Dependent Variable: RT

Sumber : Hasil SPSS versi 10 
Dari tabel diatas diketahui bahwa nialai Durbin-Watson (DW) sebesar 2,263. Jika DW dibandingkan pada $\mathrm{p}=0,05 ; \mathrm{N}=38$ dan $\mathrm{K}=2$ didapatkan sebagai berikut: $\mathrm{Du}=1,594 ; \mathrm{DI}=$ 1,373 dan 4 -du $=2,41$. Oleh karena $d u<d<4$ du maka dapat disimpulkan bahwa tidak terdapat autokorelasi.

Berdasarkan hasil uji asumsi klasik diatas maka dapat disimpulkan bahwa data tersebut layak untuk uji statistik karena telah memenuhi semua kriteria asumsi klasik.

\section{Pengujian Hipotesis}

Teknik analisis data yang digunakan adalah metode regresi linear berganda yang menjelaskan pengaruh informasi laba (rugi) bersih dan arus kas bersih terhadap return saham. Untuk mengolah data digunakan program software SPSS versi 10 for Windows.

Nilai Coefficient Output SPSS

\section{Coefficients}

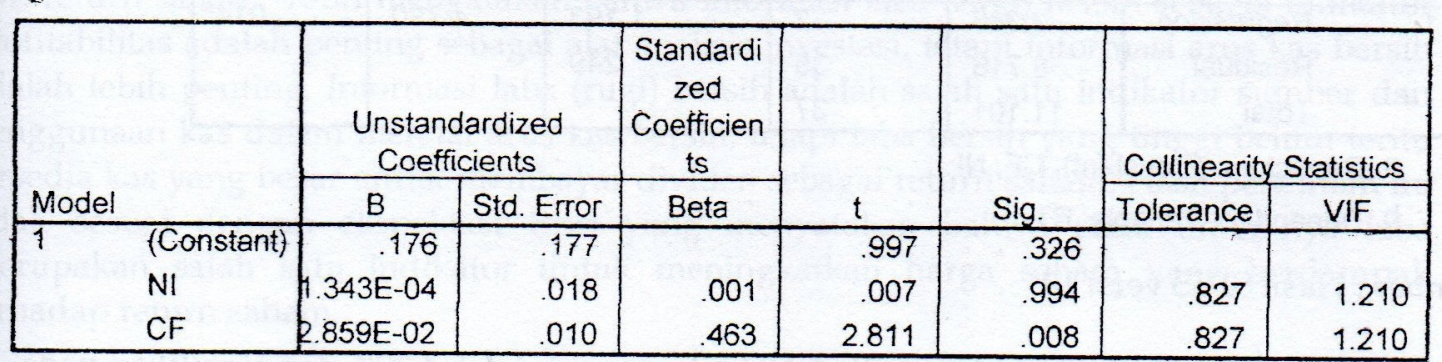

a. Dependent Variable: RT

Sumber : Hasil SPSS versi 10

Berdasarkan nilai coefficient diatas diperoleh bahwa Laba (rugi) bersih adalah dengan nilai $t-=0,007$, dan signifikan pada 0,994 . Hasil $t$ hitung lebih kecil dari $t$ tabel $(0,007<2,0281)$; dan pada tingkat signifikansi $0,994>0,05$, maka laba (rugi) bersih mempunyai pengaruh positif dan tidak signifikan terhadap return saham. Kriteria statistik menyatakan, jika t-hitung $>\mathrm{t}$ tabel pada tingkat signifikansi alfa $>0,05$, maka Ho diterima, Maka Ho yang menyatakan laba (rugi) bersih tidak berpengaruh terhadap return saham ditolak. Nilai signifikansi 0,994 $>0,05$, mengindikasikan bahwa laba (rugi) bersih berpengaruh positif dan tidak signifikan terhadap return saham. Maka hipotesis penelitian yang menyatakan laba (rugi) bersih berpengaruh positip dan signifikan terhadap return saham pada perusahaan manufaktur Automotive and Allied Products yang terdaftar di Bursa Efek Indonesia ditolak. Dengan demikian Hipotesis (H1) ditolak.

Berdasarkan hasil SPSS versi 10 diatas diperoleh bahwa nilai koeficien Arus kas bersih adalah dengan nilai $t-=2,811$, dan signifikan pada 0,008 . Hasil $t$ hitung lebih kecil dari $t$ tabel $(2,811<2,8281)$; dan pada tingkat signifikansi $0,008<0,05$, maka Arus kas bersih berpengaruh positif dan signifikan terhadap return saham. Kriteria statistik menyatakan, jika thitung $>$ t-tabel pada tingkat signifikansi alfa $>0,05$, maka Ho diterima, Maka Ho yang menyatakan Arus kas bersih tidak berpengaruh terhadap return saham ditolak. Nilai signifikansi $0,008<0,05$, mengindikasikan bahwa Arus kas bersih berpengaruh signifikan terhadap return saham. Maka hipotesis penelitian yang menyatakan Arus kas bersih berpengaruh positip dan signifikan terhadap return saham pada perusahaan manufaktur Automotive and Allied Products yang terdaftar di Bursa Efek Indonesia diterima. Dengan demikian Hipotesis ( $\mathrm{H} 2)$ diterima. 
Maka secara parsial bahwa laba (rugi) bersih berpengaruh positif dan tidak signifikan terhadap return saham, pada perusahaan manufaktur Automotive and Allied Products yang terdaftar di Bursa Efek Indonesia, sedangkan Arus kas bersih berpengaruh positip dan signifikan terhadap return saham pada perusahaan manufaktur Automotive and Allied Products yang terdaftar di Bursa Efek Indonesia.

\section{Uji anova (Uji- F)}

Uji ini dilakukan untuk melihat pengaruh secara bersam-sama (pengaruh simultan) Laba (rugi) bersih dan Arus kas bersih terhadap return saham pada perusahaan automotive and allied product yang terdaftar di Bursa Efek Indonesia. Hasil Uji Anova adalah sebagai berikut:

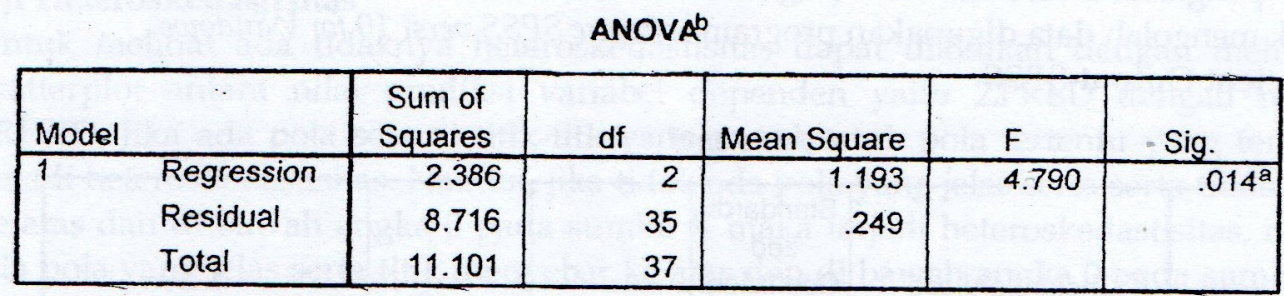

a. Predictors: (Constant), CF, NI

b. Dependent Variable: RT

Sumber : Hasil SPSS versi 10

Dari uji F (ANOVA Test) diatas dapat diketahui nilai $F_{\text {hitung }}$ adalah 4,790, dan signifikan pada

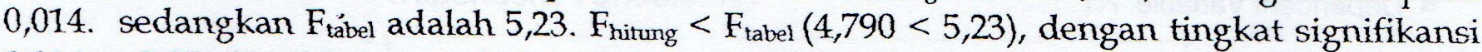
$0,014<0,05$. Hasil ini menjelaskan bahwa Laba (rugi) bersih dan Arus kas bersih secara simultan berpengaruh positif dan signifikan terhadap return saham pada perusahaan manufaktur Automotive and Allied Products yang terdaftar di Bursa Efek Indonesia. Jika Fhitung $>$ F-tabel pada tingkat signifikansi alfa $>0,05$, maka Ho diterima. Maka Ho yang menyatakan Laba (rugi) bersih dan arus kas bersih tidak berpengaruh terhadap return saham adalah ditolak. Dengan demikian maka laba (rugi) bersih dan arus kas bersih secara simultan berpengaruh positif dan signifikan terhadap return saham pada perusahaan manufaktur Automotive and Allied Products yang terdaftar di Bursa Efek Indonesia.

Dari hasil diatas maka model persamaan regresi adalah sebagai berikut:

$$
\mathrm{Y}=0,176+1,000343 \times 1+2,0859 \times 2+\mathrm{e}
$$

thitung $)=(0,997) \quad(0,007) \quad(2,811)$

Persamaan di atas memberikan penjelasan bahwa ontuk laba (rugi) bersih sebesar $1 \%$ akan menaikkan tingkat return saham sebesar 1,000343 dan untuk arus kas bersih $1 \%$ akan menaikkan tingkat return saham sebesar 2,0859. Dan jika laba (rugi) bersih dan arus kas bersih sama dengan nol maka return saham yang diperoleh perusahaan sebesar 0,176.

\section{Pembahasan}

Hasil pengolahan data menunjukkan nilai $\mathrm{R}$ sebesar 0,464 atau $46,4 \%$, berarti bahwa kedua variabel independen, yaitu laba (rugi) bersih dan arus kas bersih secara bersama-sama memiliki hubungan dengan variabel dependen yaitu return saham sebesar $46,4 \%$. Nilai $R$ Square sebesar 0,215 atau 21,5\%; berarti kemampuan variabel independen yaitu laba (rugi) bersih dan arus kas bersih secara bersama-sama dalam menjelaskan variabel dependen yaitu return saham sebesar $21,5 \%$, sedangkan sisanya sebesar $78,5 \%(100 \%-21,5 \%)$ dijelaskan 
oleh variabel lain. Faktor-faktor lain yang mungkin lebih besar pengaruhnya terhadap return saham adalah kondisi ekonomi, nilai kurs, suku bunga SBI, dan struktur modal.

\section{Pengaruh Laba (rugi) Bersih terhadap Return Saham}

Dari hasil pengolahan data menunjukkan hasil bahwa nilai koefisien dari laba (rugi) bersih (nilai t-hitung) adalah positif dan lebih kecil dari nilai t-tabel $(0,007<2,0281)$; artinya secara parsial laba (rugi) bersih berpengaruh terhadap return saham dan pengaruhnya tidak signifikan karena tingkat signifikansi $0,994>0,05$. Karena thitung $<t_{\text {tabel }}$ dan signifikan pada $0,994>0,05$, maka laba (rugi) bersih berpengaruh positif yang tidak signifikan terhadap return saham. Dengan demikian informasi laba (rugi) bersih berpengaruh terhadap harga saham, yang berdampak terhadap return saham, tetapi pengaruh tersebut tidak signifikan.

Implikasi praktisnya bahwa investor dan calon investor kurang dipengaruhi oleh informasi laba (rugi) bersih untuk berinvestasi dalam saham yang berdampak terhadap harga saham dan return saham. Teori mengatakan bahwa informasi laba (rugi) bersih sebagai indikator profitabilitas adalah penting sebagai alat analisis investasi, tetapi informasi arus kas bersih adalah lebih penting. Intormasi laba (rugi) bersih adalah salah satu indikator sumber dan penggunaan kas dalam menilai arus kas bersih, tetapi laba bersih yang tinggi belum tentu tersedia kas yang besar untuk membayar dividen sebagai return saham. Hasil penelitian ini tidak sesuai dengan ekspektasi teori yang menyatakan bahwa pada umumnya laba merupakan salah satu indikator untuk meningkatkan harga saham yang berdampak terhadap return saham.

Jika pendapatan naik maka laba juga akan naik, sehingga memungkinkan bagi pemegang saham untuk memperoleh dividen yang tinggi sebagai keuntungan atas investasi saham. Dividen yang meningkat akan mengakibatkan return saham juga meningkat, tetapi laba yang meningkat tersebut boleh jadi merupakan kenaikan aktiva bersih dalam piutang yang sifatnya kontijen ataupun dalam persediaan. Dengan demikian informasi laba (rugi) bersih kurang mempengaruhi keputusan investor dan calon investor untuk berinvestasi dalam saham yang berdampak terhadap harga saham dan meningkatkan return saham. Jadi laba yang semakin meningkat yang mengakibatkan dividen per lembar saham meningkat, belum tentu return saham juga akan meningkat, karena investor lebih cenderung melihat kemampuan membayar dividen sebagai pengembalian investasi (return saham)

\section{Pengaruh Arus Kas Bersih terhadap Return Saham}

Nilai koefisien dari arus kas bersih ( $t$-hirung) adalah positif $(2,811)$ dan nilai $t$-tabel $(2,8281)$ dimana $t$-hit $<t$-tabel $(2,811<2,8281)$ dan signifikan pada 0,008 , dimana $0,008<0,05$. Hasil ini mengindikasikan bahwa arus kas bersih berpengaruh positip dan signifikan terhadap return saham. Artinya bahwa dalam mempertimbangkan pembelian saham, investor lebih mempertimbangkan arus kas perusahaan tersebut karena arus kas mempunyai pengaruh yang positif dan signifikan terhadap return saham.

Laba bersih adalah hal yang penting, tetapi arus kas lebih penting lagi karena dividen harus dibayar secara tunai dan karena kas diperlukan dalam membeli aktiva untuk melanjutkan operasi perusahaan dan membayar dividen sebagai return saham. Nilai setiap aktiva dan saham, tergantung pada arus kas yang dihasilkan oleh aktiva tersebut, maka manajer harus berusaha memaksimalkan arus kas yang tersedia bagi investor dalam jangka panjang. Arus kas bersih pada umumnya berbeda dengan laba akuntansi, karena beberapa pendapatan dan beban yang tercantum dalam laporan laba-rugi tidak dibayar secara tunai dalam satu tahun (accrual basis). Wilson dalam penelitiannya menyatakan bahwa secara parsial ada 
pengaruh positif dan signifikan dari arus kas terhadap return saham. Maka hasil penelitian ini sesuai dengan ekspektasi teori.

\section{Pengaruh Laba(rugi) Bersih dan Arus Kas Bersih terhadap Return Saham}

Dari hasil uji ANOVA diketahui bahwa nilai $F_{\text {hitung }}$ sebesar 4,790, sedangkan $F_{\text {tabel }}$ sebesar 5,23 signifikansi pada 0,014. F-hit $<$ F-tabel $(4,790<5,23)$ dan $0,014<0,05$ mengindikasikan bahwa laba (rugi) bersih dan arus kas bersih secara simultan berpengaruh positip dan signifikan twehadap return saham pada perusahaan manufaktur Automotive and Allied Products yang terdaftar di bursa Efek Indonesisa. Hasil ini sesuai dengan ekspektasi reori yang mengatakan bahwa informasi laba (rugi) bersih dan arus kas bersih adalah penting sebagai dasar analisis untuk ketertarikan investor dan calon investor untuk investasi dalam saham yang berdampak terhadap kenaikan harga saham dan return saham.

\section{Kesimpulan}

Penelitian ini menganalisis pengaruh laba (rugi) bersih dan arus kas bersih terhadap return saham pada perusahaan manufaktur Automotive and Allied Products yang terdaftar di Bursa Efek Indonesia. Dari hasil penelitian dapat disimpulkan sebagai berikut:

1. Hasil uji $F$, diperoleh bahwa $F$ hitung sebesar 4,790 dan $F$ tabel sebesar 5,23 , signifikan pada 0,014 , dimana $F_{\text {hitung }}<F_{\text {tabel; }}$ dan $0,014<0,05$, mengindikasikan bahwa laba (rugi) bersih $\left(X_{1}\right)$ dan arus kas bersih $\left(X_{2}\right)$ secara simultan berpengaruh positif dan signifikan terhadap return saham $(\mathrm{Y})$ pada perusahaan manufaktur Auyomotive and Allied Products yang terdaftar di Bursa Efek Indonesia.

2. Nilai koefisien determinanya sebesar 0,215 atau $21,5 \%$, mengindikasikan bahwa return saham (Y) dapat dijelaskan oleh laba (rugi) bersih (X1) dan arus kas bersih (X2) sebesar $21,5 \%$, sedangkan sisanya sebesar 78,5\% dijelaskan oleh variabel lain.

3. Nilai koefisien laba (rugi) bersih $(X 1)$ dengan nilai t-hitung sebesar 0,007 dan $t$-tabel sebesar 2,0281 dengan nilai signifikansi 0,994, dimana thitung < $t$-tabel dan 0,994 > 0,05 , mengindikasikan bahwa laba (rugi) bersih (X1) secara parsial berpengaruh positif dan tidak signifikan terhadap return saham $(Y$ ) pada perusahaan manufaktur Automotive and Allied Products yang terdaftar di Bursa Efek Indonesia. Dengan demikian Hipotesis (H1) ditolak.

4. Nilai koefisien arus kas bersih $(X 2)$ dengan nilai thitung sebesar 2,811 dan $t$-tabel sebesar 2,8281 dengan nilai signifikansi 0,008, dimana $t$-hitung $<t$-tabel dan $0,008<$ 0,05 , mengindikasikan bahwa arus kas bersih $\left(X_{2}\right)$ secara parsial berpengaruh positif dan signifikan terhadap retum saham $(Y)$ pada perusahaan manufaktur Automotive and Allied Products yang terdaftar di Bursa Efek Indonesia. Dengan demikian Hipotesis ( $\mathrm{H} 2)$ diterima.

5. Hasil penelitian ini konsiten dengan hasil penelitian Wilson yang menyatakan bahwa secara parsial arus kas berpengaruh positif dan signifikan terhadap return saham. Hasil penelitian Eric yang menyatakan bahwa arus kas dan laba bersih mempunyai hubungan dengan return saham adalah konsisten dengan hasil penelitian ini. Hasil penelitian Ali menyatakan bahwa laba berpengaruh signifikan terhadap return saham, tidak konsisten dengan hasil penelitian ini.

6. Penelitian ini memiliki keterbatasan yaitu jumlah variable dan variabel control serta sampel masih sangat sedikit sehingga hasilnya belum dapat digeneralisasi. Maka untuk peneliti selanjutnya, sebaiknya menambah variabel dan menambah sampel penelitian untuk mendapatkan hasil yang lebih akurat. 


\section{DAFTAR PUSTAKA}

Bursa Efek Indonesia., 2008. Data perusahaan tercatat di BEI. www.jsx.co.id www.jsx.co.id/ laporan keuangan/soft copy laporan keuangan 2008

Eric, L,C,1997. "Impac of Earning, Dividends and Cash flows on stock; Return: Case of Taiwan's Stock Market," Riview of Quantitative Finance and Accounting 9 (1997).

Bringham, E.F., dan J.F.Houstun.,2001." Manajemen Keuangan", Cetakan Ketujuh, Edisi kedelapan, Jakarta: Penerbit Erlangga.

IAI, 2002, SAK, Salemba empat Jakarta.

Imam Ghozali,2005. Aplikasi Analisis Multivariat dengan program SPSS, Edisi 11.

Institute for Economic and Financial Research, 2008. Indonesian Capital Market Directory. Jogianto, H,M, 2003. Toeri Portofolio dan Analisis Investasi. BPEE. Yogyakarta.

Sugiyono, 2009. Metode Penelitian Pendidikan. Cetakan ketujuh. Penerbit Alfabeta Bandung.

Simamora, Henry., 2001. Akuntansi Basis Pengambilan Keputusan Bisnis. Jilid 11. Cetakan pertama. Penerbit Salemba Empat.

Wilson, G.P, "The Relative Information of Accrual and cash flow: Combined Evidence at The Earning Announcement and Annual Reporting Release". 